structural perfection to suggest that they were functional ; and it is noteworthy that in both cases active haemopoiesis was in progress in the hepatic tissue.

I conclude with the following words of Sir James Paget (1882), who, writing about the structural study of malformations, said: "Not one of them is without meaning; not one that might not become the beginning of excellent knowledge, if only we could answer the question-why is this rare? or, being rare, why did it in this instance happen ?" Roy Cameron set a perfect example of that nicely balanced combination of morphological and experimental inquiry which is essential for elucidating why things happen.

I am deeply indebted to many fellow pathologists for sending me the specimens described and for their permission to record them; I have given their names in the case reports. Most of the photographs are the work of Mr. Gerald Leach, of the Imperial Cancer
Research Fund, London; and to him and to Dr. Stretton Young, head of its Division of Pathology, I am very grateful.

\section{REFERENCES}

Aterman, K., and Abaci, F. (1967). Amer. F. Dis. Child., 113, 552. Ballantyne, J. W. (1902). Manual of Antenatal Pathology and Hygiene, vol. I. Edinburgh.

Burne, J. C. (1958). F. Path. Bact., 75, 470.

Dosch, F. (1941). Beitr. path. Anat., 105, 244.

Kellett, H. S., Lipphard, D., and Willis, R. A. (1962). F. Path. Bact.,

Lee, M. C. L., and Aterman, K. (1968). Amer. F. Dis. Child. In press.

Marsden, H. B., and Gilchrist, W. (1963). F. Path. Bact., 86, 532 .

Paget, J. (1882). Lancet, 2, 1017.

Pugh, R. J., Feather. D. B., and Goldie, W. (1958). Brit. F. Surg., 46. 83.

Schultz, L. (1927). Arch. Path. Lab. Med., 4, 359.

Willis, R. A. (1962a). The Borderland of Embryology and Pathology, 2nd ed. London.

Willis, R. A. (1962b). Pathology of the Tumours of Children. Edinburgh and London.

\title{
Detection of Allergy to Penicillin and Other Antigens by In-vitro Passive Sensitization and Histamine Release from Human and Monkey Lung
}

\author{
E. S. K. ASSEM,* PH.D., M.R.C.P. ; H. O. SCHILD, † M.D., PH.D., D.SC., F.R.S.
}

\begin{abstract}
Summary : Preparations of chopped human and monkey $S$ lung were used to estimate the reaginic activity of serum from allergic patients. The lung preparation was passively sensitized by incubation with serum taken from the patients, and then challenged with the antigen responsible for the allergy. Measurement of the histamine released from the lung gave a quantitative assessment of the level of reaginic activity in the patient's serum.

Tests were done on patients allergic to four natural antigens, including grass pollen, and to penicillin. Human lung proved more sensitive and possibly more specific than monkey lung in testing for natural allergies. The results of testing for penicillin allergies were less satisfactory, possibly because of the difficulty of reconstructing the appropriate antigen.
\end{abstract}

\section{Introduction}

Histamine release from the tissues of an allergic individual was first demonstrated by Katz and Cohen (1941), who found that whole blood of a subject with ragweed hypersensitivity liberated histamine when incubated with antigen. It was later shown that pieces of lung removed at operation from a pollen-allergic patient released histamine when incubated with pollen (Schild, Hawkins, Mongar, and Herxheimer, 1951). Histamine liberation from whole blood or isolated human leucocytes by incubation with a specific antigen has since been made into a quantitative procedure (Noah and Brand, 1955 ; VanArsdel, Middleton, Sherman, and Buchwald, 1958 ; Lichtenstein and Osler, 1964).

The tests discussed so far reflect active sensitization and are essentially comparable to the weal and flare reaction which follows the intradermal injection of an antigen in a sensitized patient.

\footnotetext{
- Wellcome Research Fellow, Department of Pharmacology, University College, London, and Medical Unit, University College Hospital Medical School, London W.C.1. t Professor of Pharmacology. University College, London W.C.1.
}

Another set of tests, also based on histamine release, is concerned with the demonstration of circulating reagins. These involve the passive sensitization of normal tissues with allergic sera in vitro followed by antigen addition and histamine release. These tests are essentially comparable to the Prausnitz-Küstner reaction, in which the serum of an allergic patient is injected intradermally into a normal subject, who is then tested with the antigen. Procedures of passive sensitization of normal tissues in vitro followed by histamine release with antigen were first developed for chopped guinea-pig lung (Mongar and Schild, 1957b ; Brocklehurst, Humphrey, and Perry, 1961), but guinea-pig tissue is unsuitable for the measurement of human reagins, which will sensitize only human or other primate tissues (Benacerraf, 1968). Human tissues which are suitable for passive sensitization and histamine release in vitro are normal leucocytes (Middleton, Sherman, Fleming, and VanArsdel, 1960 ; Lichtenstein and Osler, 1964) and chopped lung (Parish, 1967 ; Sheard, Killingback, and Blair, 1967 ; Augustin, 1967 ; Bukhari, 1967 ; Brocklehurst, 1968); a suitable monkey tissue is chopped lung (Goodfriend, Kovacs, and Rose, 1966).

In the present study human and monkey chopped lung has been used, and the suitability of the two species for the detection and measurement of the reaginic activity of human serum compared. The initial experiments were carried out with sera of patients allergic to pollen and other environmental antigens. The establishment of a drug reactions reporting system at University College Hospital has proved an opportunity of studying a number of patients with penicillin allergy and to investigate whether they carried reagins capable of sensitizing lung tissue in vitro.

\section{Material}

Penicillin Allergy.-Twenty-two patients were investigated for penicillin allergy; in eight of these (Cases 12-19) the clinical diagnosis of penicillin allergy was established, as these patients "reacted" to penicillin on two or more occasions. 
In another nine patients (Cases 20-28) the diagnosis was probable, and in the remaining five (Cases 29-33) it was possible. The uncertainty in the diagnosis of penicillin allergy in these patients was partly due to the simultaneous administration of other drugs. Some of the latter 14 patients had had previous courses of penicillin without any reaction, while others denied previous penicillin therapy. No mention is made here of the different penicillin derivatives which caused these reactions, but these derivatives were included so far as possible in the material for in-vitro tests. In 10 out of the 22 patients the investigations were carried out 7 to 30 days after the reaction, and in two of these (Cases 13 and 18) tests were repeated on three occasions within that period. All drugs capable of suppressing allergic reactions were discontinued at appropriate times before the tests. Two patients (Cases 18 and 20) had also apparently reacted to cephaloridine (Ceporin), which they received immediately after the discontinuation of penicillin. One of these patients (Case 20) continued to have recurrent urticarial rashes and angioneurotic oedema for several weeks after both of these antibiotics had been discontinued.

Allergy to Natural Antigens.-Eleven patients with wellconfirmed allergies comprised this group; 10 were suffering from grass-pollen allergy, and one of these (Case 8) was also allergic to the moulds Alternaria tenuis and Cladosporium herbarum. Serum from one of these patients was provided by Dr. W. E. Brocklehurst, and another (Case 5) by Miss J. M. Dewdney at Beecham Research Laboratories. One patient (Case 7) was allergic to horse dandruff, and his serum was provided by Dr. D. R. Stanworth.

Non-allergic Controls.-Seven volunteers were included as controls for the various allergies. Another volunteer ( $\mathbf{H}$.), who was allergic only to grass pollen, was also used as a control for penicillin allergy.

\section{Methods}

\section{Skin Tests}

Tests for penicillin allergy consisted of intradermal injection of 50-200 units of benzylpenicillin in $0.02 \mathrm{ml}$. of saline, and $0.02 \mathrm{ml}$. of a solution of penicilloyl-polylysine in phosphatebuffered saline containing $6 \times 10^{-5} \mathrm{M}$ penicilloyl (Cilligen, Sigma Chemical Co.). An intradermal test with cephaloridine was also carried out in Case 20.

Eight of the 11 patients with other allergies were under the care of Dr. M. McAllen. These patients had quantitative skin tests with the corresponding antigens, and four of them (Cases $3,4,6$, and 11) had a quantitative bronchial tolerance test (McAllen, Heaf, and McInroy, 1967). The other three patients also had extensive investigations, including direct and Prausnitz-Küstner skin tests. The non-allergic volunteers had skin tests with benzylpenicillin, penicilloyl-polylysine, and grass pollen.

\section{Serum Antibodies}

Blood was collected before carrying out skin tests, and antibodies of various types were investigated. Only the methods of detecting reaginic antibodies are described here.

\section{Biological Estimation of Reaginic Antibodies}

The method involves the sensitization of chopped human or monkey lung tissue by in-vitro incubation with serum containing reagins and subsequent challenge with the antigen which releases histamine into the supernatant fluid. By measuring the histamine content of the supernatant fluid and that remaining in the lung tissue the percentage of histamine released can be calculated. The procedure is based on that described by Mongar and Schild (1957a, 1960).
Pieces of apparently normal human lung were obtained at operation from patients with bronchial carcinoma. The lung specimens were placed in sterile Tyrode solution at room temperature, and used within a few hours. Lungs were also obtained from normal rhesus monkeys weighing approximately $8 \mathrm{lb}$. (3.6 kg.).

A homogeneous suspension of small pieces of lung tissue measuring 0.25 by $0.25 \mathrm{~mm}$. in cross-section was prepared as follows. The tissue was first cut with scissors and then by a mechanical chopper (Mcllwain and Buddle, 1953). The chopped lung was washed with Tyrode solution until the washing fluid was free from colour. The fluid was removed with the help of a nylon suction brush as described by Brocklehurst et al. (1961). Up to 60 drained tissue aliquots, weighing about $140 \mathrm{mg}$. each, were measured by volume, by means of a tissue sampler consisting of a Perspex plate with even-sized holes. The samples were placed in flat-bottomed specimen tubes, and incubated with $1.5 \mathrm{ml}$. of different dilutions of serum for 14 to 20 hours at room temperature, duplicate samples being used. The tubes were covered with Oxoid caps and kept in a rocking bath. No antibiotics were added.

At the end of incubation the serum was removed, lung specimens were washed three times with 4-ml. aliquots of Tyrode solution, after which $1 \mathrm{ml}$. of Tyrode solution was added and the tubes were put in a rocking bath at $37^{\circ} \mathrm{C}$. Five minutes later the sensitized lung was challenged with 1-ml. aliquots of different concentrations of antigen and incubated for 15 minutes, after which the supernatant containing the released histamine was removed by means of a capillary-tipped pipette loosely plugged with teased cotton-wool. Aliquots of Tyrode solution were added to the lung tissue left behind in the specimen tubes, and the histamine content of the tissue was released by placing the tubes in boiling water for 10 minutes. It was assumed that total histamine $=$ histamine released by antigen + histamine released by boiling. All solutions were stored frozen until their histamine content was assayed.

Histamine was estimated biologically by the use of guineapig ileum suspended in Tyrode solution containing $3 \times 10^{-7} \mathrm{M}$ atropine sulphate, an automatic assay apparatus (Boura, Mongar, and Schild, 1954) being used. Responses to dilutions of each unknown solution were bracketed between responses to two standard solutions of histamine as shown in Fig. 1, and

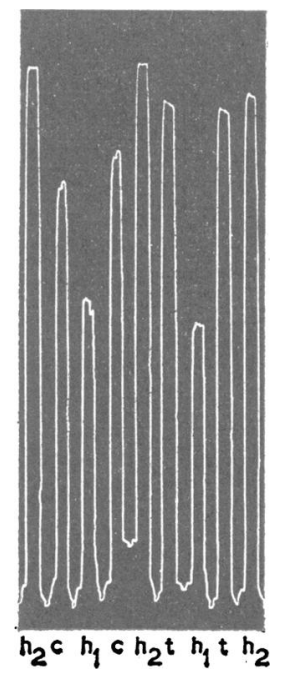

Fig. 1.-Biological assay on isolated guineapig ileum of histamine released from human lung. $h_{1}, h_{2}=$ Histamine standards, 2.5 and 5 by $10^{-9}$ respectively ; $c=$ Control $=$ supernatant (diluted seven times) after applying pollen extract to unsensitized lung ; $t=T$ est $=$ pollen extract to unsensitized lung; $\mathrm{t}=\mathrm{T}$ est $=$
supernatant (diluted 70 times) after applying pollen extract to lung passively sensitized by incubation with serum of a pollen-allergic patient. Note steep dose-response curve of histamine. Histamine content of test solution is about 12 times that of control.

their histamine content was calculated, assuming a linear relationship between $\log$ dose and response. The effect of the released material could be abolished by mepyramine, confirming its identity with histamine.

Samples in which unsensitized lung was incubated with antigen were used as controls. Other controls were samples not challenged with antigen after incubation of the lung with reaginic sera. 


\section{Antigens}

All antigen solutions were prepared in Tyrode solution. In penicillin allergy, sensitized lung was challenged by : $(a)$ benzylpenicillin, 100-1,000 units/ml., (b) penicilloyl-polylysine, $1 \times$ $10^{-5}$ to $6 \times 10^{-7} \mathrm{M}$, and $(c)$ a macromolecular fraction separated from benzylpenicillin, on Sephadex-G10, as shown in Fig. 2B. After this separation, the fraction was dialysed against several changes of Tyrode solution for 24 hours at $4^{\circ} \mathrm{C}$. The yield from $1 \mathrm{~g}$. benzylpenicillin was equivalent to $0.5-1 \mathrm{mg}$. of protein as determined by Folin-Ciocalteu reagent, human serum albumin being used as reference. The benzylpenicillin which has been freed from this fraction or Purapen $G$ obtained from Beecham Research Laboratories (Fig. 2A) was also used in some experiments. It should be mentioned that when these purified penicillin preparations were rerun on Sephadex-G10 they were found to contain a small amount of macromolecular material which seems to have resulted from the polymerization of penicillin.

In pollen allergy mixed grass-pollen (A12 and Pollaccine), 50-200 Noon units/ml. was used. The moulds Alternaria tenuis and Cladosporium herbarum were used in 1/400 dilution of the $10 \%$ extract in Coca's solution. The horse-dandruff antigen was provided by Dr. Stanworth, and $0.02 \mathrm{ml}$. of this antigen was added to each lung specimen in a final volume of $2 \mathrm{ml}$.

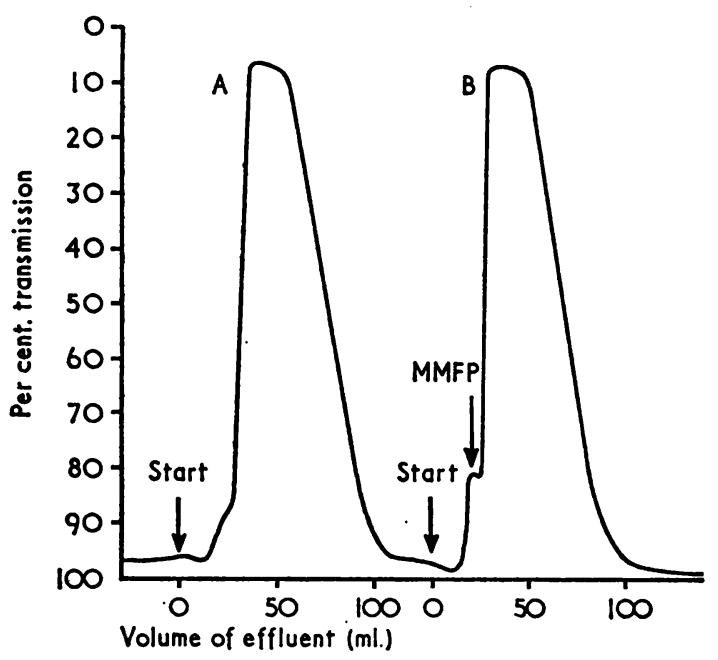

FIG. 2.-Chromatography of two penicillin preparations on a 30 by $1.5 \mathrm{~cm}$. Sephadex-G10 column. Transmission of ultraviolet light at $254 \mathrm{~nm}(\mathrm{~m} \mu)$. A, Purapen G. B, Benzylpenicillin (Crystapen). MMFP is the macromolecular fraction of penicillin mentioned in the text.

\section{Results}

\section{Allergy to Natural Antigens}

Findings from the 10 patients with pollen allergy, one of whom also had mould allergy, and one with horse dandruff allergy are summarized in Table I, which also includes data from seven control subjects.

All except one of the allergic sera produced substantial histamine releases after passive sensitization of human lung. Control sera gave negligible releases. Expressed in terms of the histamine content of the lung, the positive sera produced net histamine releases ranging from 3.7 to $71.8 \%$. Another method of estimating activity was by means of reaginic antibody " titres." The reaginic titre was defined as the highest dilution of a reaginic serum, which after incubation with lung produced a histamine release with antigen of twice that obtained with the same antigen in untreated lung. With the human lung preparation antibody titres of 10 positive sera ranged from 5 to 1,200 . The total histamine releases mentioned in Table I represent the highest points on the calibration curve used for obtaining reaginic antibody titres. ${ }^{1}$ The histamine release values obtained in monkey lung were consistently less than in the human lung, the maximum net release being $6.2 \%$. Nevertheless releases by 9 out of 11 sera were significantly above control levels. Reagin titres in monkey lung ranged from 3 to 420 .

The degree of correlation between histamine releases from human and monkey lung was estimated by means of Spearman's coefficient of rank correlation. Histamine releases showed no significant correlation, but reaginic antibody titres were significantly correlated $(R=0.71 ; 0.02<P<0.05)$.

The allergic subject (Case 11) whose serum failed to sensitize either human or monkey lung was further investigated. Direct skin tests were positive. In-vitro challenge of the patient's own leucocytes, carried out by Miss $\mathrm{N}$. Topping, gave strongly positive results for histamine release, suggesting that the occurrence of circulating reagins and of active sensitization of tissues may not necessarily run parallel.

\section{Penicillin Allergy}

Twenty-two patients with diagnosed or suspected penicillin allergy were investigated along with a control group. Table II summarizes the findings obtained. It has been subdivided

'A detailed account of this quantitative method of measuring the reaginic activity of sera will be published by one of us (E.S.K. A.).

TABle I.-Histamine Release from Passively Sensitized Lung (Percentage of Total) and Titres of Reaginic Antibodies Against Natural Antigens

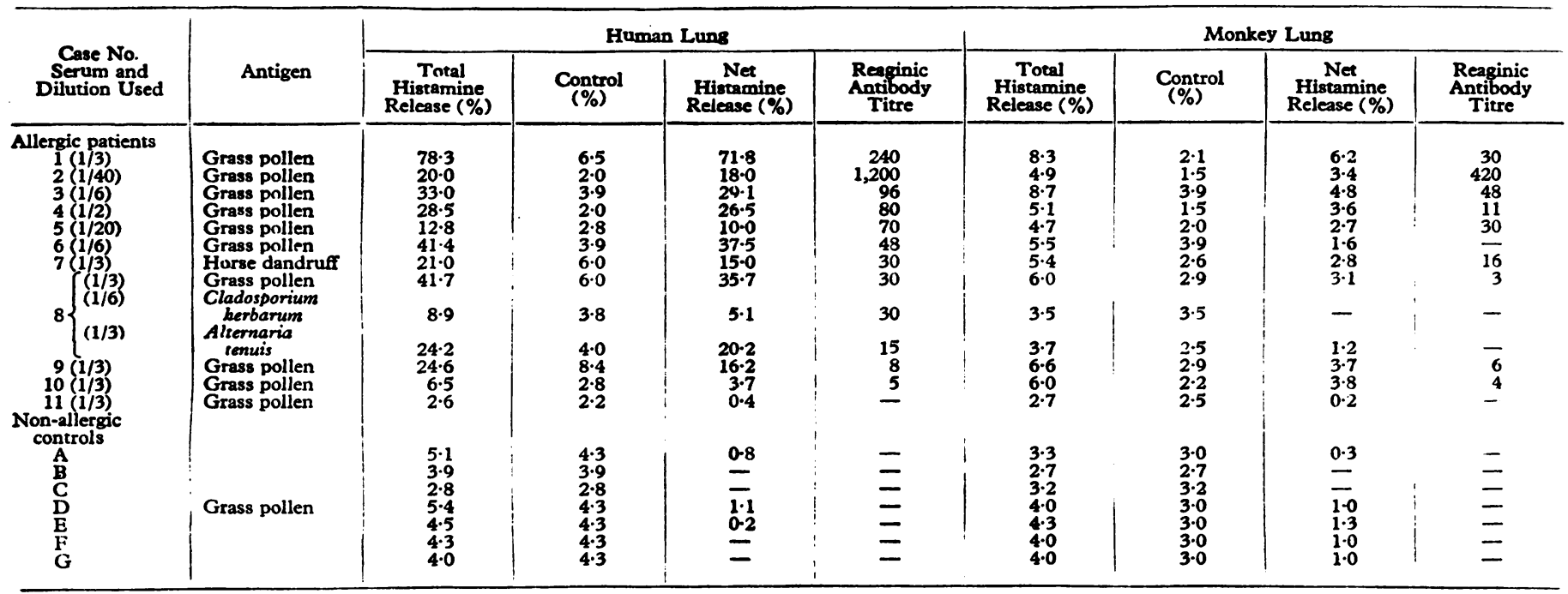


TABLE II.-Tests for Penicillin Allergy

\begin{tabular}{|c|c|c|c|c|c|c|c|c|c|c|c|c|}
\hline \multirow{2}{*}{$\begin{array}{l}\text { Case } \\
\text { No. }\end{array}$} & \multicolumn{2}{|l|}{ Skin Tests } & \multicolumn{5}{|c|}{ Passive Sensitization of Human Lung } & \multicolumn{5}{|c|}{ Passive Sensitization of Monkey Lung } \\
\hline & PN & PPL & $\begin{array}{c}\text { No. of } \\
\text { Tests }\end{array}$ & $\begin{array}{l}\text { Positive } \\
\text { Tests }\end{array}$ & PN & PPL & MMFP & $\begin{array}{l}\text { No. of } \\
\text { Tests }\end{array}$ & $\begin{array}{l}\text { Positive } \\
\text { Tests }\end{array}$ & PN & PPL & MMFP \\
\hline $\begin{array}{l}12 \\
13 \\
14 \\
15 \\
16 \\
17 \\
18 \\
19\end{array}$ & $\begin{array}{c}+++,++\stackrel{+}{+}+,++++ \\
+ \pm \\
= \\
- \pm,-\end{array}$ & $\begin{aligned}- & \frac{ \pm}{+},+ \\
& \pm \\
- & = \\
+ & +\end{aligned}$ & $\begin{array}{l}2 \\
3 \\
3 \\
1 \\
2 \\
2 \\
2 \\
1\end{array}$ & $\begin{array}{l}2 \\
2 \\
1\end{array}$ & Lblished & $\begin{array}{l}\text { icillin } A \\
-, \overline{ \pm} \\
\overline{ \pm} \\
\bar{\Xi} \\
\overline{+}\end{array}$ & 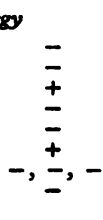 & $\begin{array}{l}2 \\
3 \\
2 \\
1 \\
2 \\
2 \\
1 \\
1\end{array}$ & $\begin{array}{l}2 \\
2 \\
1 \\
2 \\
1 \\
1\end{array}$ & $\begin{array}{l}-, \pm \\
\pm \\
\pm \\
+ \pm+\end{array}$ & $\begin{array}{l} \pm \\
\pm \\
\pm \\
\pm \\
+\end{array}$ & $\begin{aligned} &- \pm \\
& \pm \\
&= \\
& \pm+ \\
&++ \\
&+\end{aligned}$ \\
\hline $\begin{array}{l}20 \\
21 \\
22 \\
23 \\
24 \\
25 \\
26 \\
27 \\
28 \\
29 \\
30 \\
31 \\
32 \\
33\end{array}$ & $\begin{array}{l} \pm \\
\pm \\
\pm \\
\pm \\
= \\
= \\
\text { N.D. } \\
= \\
=\end{array}$ & $\begin{array}{c}+ \pm+ \\
\pm \\
= \\
\overline{ \pm} \\
\overline{=} \\
\text { N.D. } \\
= \\
=\end{array}$ & $\begin{array}{l}4 \\
1 \\
2 \\
1 \\
1 \\
2 \\
3 \\
1 \\
3 \\
1 \\
1 \\
1 \\
1\end{array}$ & $\begin{array}{l}4 \\
1 \\
2 \\
1 \\
1\end{array}$ & 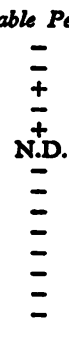 & $\begin{array}{c}\text { Alllor } \\
++++ \\
\overline{+} \\
\overline{=} \\
\text { N.D. } \\
\overline{=} \\
\overline{=} \\
\overline{=} \\
\overline{=}\end{array}$ & $\begin{array}{l} \pm+ \\
\pm \\
\pm \\
\text { N.D. } \\
\pm \\
= \\
= \\
= \\
=\end{array}$ & $\begin{array}{c}3 \\
3 \\
1 \\
1 \\
2 \\
2 \\
1 \\
1 \\
\text { N.D. } \\
1 \\
1 \\
1 \\
1\end{array}$ & $\begin{array}{c}2 \\
1 \\
\text { N.D. }\end{array}$ & 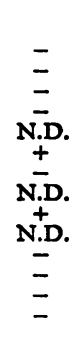 & $\begin{array}{c}\overline{-} \\
\overline{-} \\
\text { N.D. } \\
\pm \\
\text { N.D. } \\
\text { N.D. } \\
\overline{=} \\
=\end{array}$ & $\begin{array}{c}\overline{ } \\
\overline{-} \\
\text { N.D. } \\
\pm \\
\text { N.D. } \\
\text { N.D. } \\
\bar{\Xi} \\
\bar{\Xi}\end{array}$ \\
\hline $\begin{array}{l}\mathbf{A} \\
\mathbf{B} \\
\mathbf{C} \\
\mathbf{D} \\
\mathbf{B} \\
\mathbf{F} \\
\mathbf{G} \\
\mathrm{H}\end{array}$ & $\begin{array}{l}\bar{z} \\
\bar{z} \\
\bar{z} \\
\bar{z}\end{array}$ & $\begin{array}{l}\bar{z} \\
\bar{z} \\
\bar{z}\end{array}$ & $\begin{array}{l}2 \\
2 \\
2 \\
2 \\
2 \\
2 \\
2 \\
2\end{array}$ & & $\begin{array}{l}\text { Non-al } \\
= \\
\bar{z} \\
\overline{=}\end{array}$ & $\begin{array}{l}\text { Contro } \\
= \\
= \\
=\end{array}$ & $\begin{array}{l}\bar{z} \\
\bar{z} \\
\end{array}$ & $\begin{array}{l}1 \\
3 \\
1 \\
1 \\
1 \\
1 \\
1 \\
1\end{array}$ & 3 & $\begin{array}{l} \pm+ \\
= \\
= \\
=\end{array}$ & $\begin{array}{l}\bar{z} \\
\bar{z} \\
\bar{z}\end{array}$ & $\begin{array}{l}\overline{\mathbf{z}} \\
\overline{\mathbf{z}} \\
\overline{\mathbf{z}}\end{array}$ \\
\hline
\end{tabular}

PN $=$ Benzylpenicillin (unpurified). PPL $=$ Penicilloyl-polylysine. MMFP $=$ Macromolecular fraction of PN. Skin tests $=$ Diameter of weal (WW) and flare (F) in mm.:

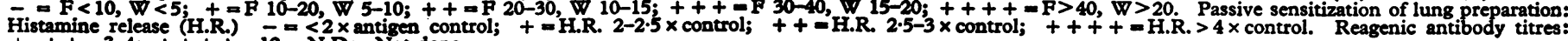
$t, t+=3-4 ;+t+t=12$. N.D. $=$ Not done.

according to the preinvestigation diagnosis into three sections of (1) eight patients (Cases 12-19) in whom the diagnosis of penicillin allergy was definitely established, each having reacted clinically to penicillin on two or more occasions ; (2) 14 patients (Cases 20-33) in whom clinical penicillin allergy was suspected but not definitely established ; and (3) a group of controls (A$\mathrm{H})$, most of whom had received penicillin previously but had shown no reactions to it. Three test antigens were used: penicillin, penicilloyl-polylysine, and a macromolecular fraction of penicillin. Only the first two were used for skin testing.

The findings in the first group of eight definitely allergic patients are summarized in Table III, which shows that only five gave positive skin tests with either benzylpenicillin or penicilloyl-polylysine; three of the sera caused histamine release from human lung and six from monkey lung. Histamine releases were generally low, of the order of two to four times control values. In the second group of doubtful penicillin reactors four patients showed positive skin reactions with one or the other antigen, five of the sera caused histamine release from human lung, and two from monkey lung. In view of the poor correlation between the various tests the results were also analysed in terms of at least one test being positive. Looked at in this way, seven out of eight patients in the first group and 8 out of 14 in the second group gave one or more positive tests. Among eight non-allergic controls none gave positive skin tests. None of their sera sensitized human lung, but one serum (B.) sensitized monkey lung on three separate occasions as evidenced by histamine release after challenge with penicillin.

TABLE III.-Summarized Findings in Eight Patients with Established Penicillin Allergy

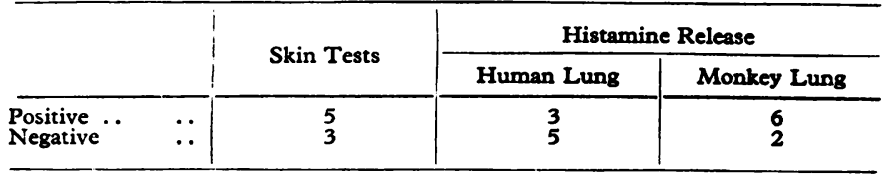

In general there was less agreement between human and monkey lung findings in this series than in the previous pollen series. In some cases there were marked discrepancies.
Case 20 responded to penicilloyl-polylysine by a weal and flare reaction; her serum produced sensitization of human chopped lung with histamine release $(26.4 \%$; control $6.5 \%$ ) after challenge by penicilloyl-polylysine. Sensitization of monkey lung was attempted on three separate occasions, but no histamine release occurred with either penicilloyl-polylysine or other penicillin antigens.

The serum of Subject B, a non-allergic control, produced sensitization of monkey lung with histamine release after challenge by benzylpenicillin, but failed to sensitize human lung. This subject had previously received penicillin without evidence of allergy. His serum contained antipenicilloyl antibodies as detected by the haemagglutination technique. This raises the possibility that human non-reaginic antibodies may sometimes be able to sensitize monkey lung.

Case 19 reacted to penicilloyl-polylysine but not to benzylpenicillin by skin test, and her serum also caused human lung sensitization to that antigen only. On the other hand, passive sensitization of monkey lung with the same serum caused a strong response to benzylpenicillin as indicated by a histamine release of $12.3 \%$ (control $2.8 \%$ ), which is the highest figure we have so far obtained from monkey lung. A smaller response to penicilloylpolylysine and macromolecular fraction of penicillin was also obtained.

In Case 20, who continued to exhibit recurrent skin rashes and angioneurotic skin after the replacement of penicillin by cephaloridine, in vitro reagin tests for allergy to cephaloridine were negative, but serum antibodies against cephaloridine were detected by the haemagglutination technique.

\section{Discussion}

Our results confirm the findings of other authors that passive sensitization of isolated human lung provides a reliable method for the detection of the reaginic activity of sera. The method can be applied not only to naturally occurring allergies but also to drug allergies, provided that a relevant antigen, which as a rule will consist of a drug protein complex or drug-metabolite protein complex, is used.

The lung test measures sensitization quantitatively by the amount of histamine released, and it can be further refined by 
carrying out serial dilutions and measuring reaginic antibody "titres." A fundamental drawback of the test as practised at present is its failure to conform to the accepted principle of biological standardization of comparison with a standard. A generally available reaginic standard could serve to "calibrate" individual lung or leucocyte preparations, thus reducing individual variability. It is to be hoped that a recognized reaginic standard preparation may in time become available.

A practical drawback of the human lung test is the potential difficulty of supply of material. It was therefore of interest to investigate monkey lung as a substitute. Our findings suggest that monkey lung may provide a possible substitute, though its sensitivity in terms of histamine release is much less than that of human lung. The reaginic antibody titres obtained in the two species were significantly correlated in the case of natural antigens, but not with penicillin. Both tests require much more investigation, especially in relation to the possibility that the monkey preparation may be capable of sensitization by human antibodies other than reagins.

The detection of reagins directed against penicillin or its degradation products presents special problems. It is known, particularly through the work of Levine, Redmond, Fellner, Voss, and Levytska (1966), which one of us (E. S. K. A.) has confirmed in unpublished observations, that non-reaginic antipenicilloyl antibodies are present in a large proportion of subjects who had received penicillin. Reaginic antibodies occur much more rarely and have been detected largely by PrausnitzKüstner tests. In view of the dangers inherent in the PrausnitzKüstner reaction it would be of great benefit if passive sensitization tests based on histamine release in vitro could be substituted for it. It was thus somewhat disappointing to find that the majority of sera of penicillin-allergic patients failed to sensitize human lung, though in several cases sensitization was achieved. The reason for the apparently low degree of sensitization by sera from penicillin-allergic patients is not obvious. One possible reason is the difficulty of reconstructing the responsible antigen, which may owe its activity to combination of a degradation product of penicillin (Levine, 1966) with a body protein. In support of this explanation is the finding that in one case of penicillin allergy (Case 19) in which substantial histamine release from human lung was produced only the penicilloyl-polylysine was active, while benzylpenicillin and macromolecular fraction of penicillin were inactive. An unexpected finding was that sensitization with penicillin sera occurred more often with monkey than with human lung.

A final point to be stressed is the distinction between the occurrence of circulating reaginic antibodies and active sensitization. Though sensitization is generally believed to be due to the fixation of reaginic antibody by tissue cells, the levels of free and tissue-bound reagin at any one time may not correspond owing to a slow establishment of equilibrium. It is therefore important to supplement reagin determinations by direct skin and leucocyte tests which measure active sensitization.
In the investigation of penicillin allergy our present practice is to carry out the following tests in sequence.

(1) Passive sensitization of human lung in order to detect serum reagins. If this test, which requires the collection of 10-20 ml. of the patient's blood, proves positive no further tests are required.

(2) In-vitro challenge of the patient's own leucocytes with penicillin, penicilloyl-polylysine, and in some cases other test antigens and measurement of the resulting histamine release. This test (not described in the present paper) requires $20-50 \mathrm{ml}$. of the patient's heparinized blood.

(3) If test 2 is negative, direct skin tests on the patient are carried out with the previously mentioned antigens.

The purpose of this graded scheme is to ensure maximum safety and convenience for the patient. In our experience subjects are unlikely to react to penicillin if all these tests prove negative; nevertheless, complete safety cannot be ensured by any test at present available. The use of the lymphocyte transformation test in penicillin allergy is under investigation.

This work was supported by grants from the Asthma Research Council and the Medical Research Council. We are gratefui to Dr. Monica McAllen for allowing us access to patients under her care, and to Dr. F. Perkins for providing monkey lung tissue. Human lung tissue was obtained through the helpful co-operation of surgeons of the Brompton and London Chest Hospitals.

\section{REFERENCES}

Augustin, R. (1967). In Handbook of Experimental Immunology, edited by D. M. Weir, p. 1076. Oxford.

Benacerraf, B. (1968). In Proceedings of Third Internationel Pharmacological Meeting, vol. II, "Immunopharmacology," edited by H. O. Schild, p. 3. Oxford.

Boura, A., Mongar, J. L., and Schild, H. O. (1954). Brit. F. Pharmacol., 9, 24.

Brocklehurst, W. E. (1968). In C.I.O.M.S. Symposium on the Biochemistry of Acute Allergic Reactions, edited by E. L. Becker and K. F. Austen. Oxford. In press.

Brocklehurst, W. E., Humphrey, J. H., and Perry, W. L. M. (1961). Immunology, 4, 67.

Bukhari, A. H. Q. (1967). Ph.D. thesis, Edinburgh University.

Goodfriend, L., Kovacs, B. A., and Rose, B. (1966). Int. Arch. Allergy, 30,511 .

Katz, G., and Cohen, S. (1941). F. Amer. med. Ass., 117, 1782.

Levine, B. B. (1966). New Engl. \%. Med., 275, 1115

Levine, B. B., Redmond, A. P., Fellner, M. J., Voss, H. E., and Levytska, V. (1966). F. clin. Invest., 45, 1895

Lichtenstein, L. M., and Osler, A. G. (1964). 7. exp. Med., 120, 507.

McAllen, M. K., Heaf, P. J. D., and McInroy, P. (1967). Brit. med. F., $1,22$.

McIlwain, H., and Buddle, H. L. (1953). Biochem. 7., 53, 412.

Middleton, E., jun., Sherman, W. B., Fleming, W., and VanArsdel, P. P. jun. (1960). \%. Allergy, 31, 448.

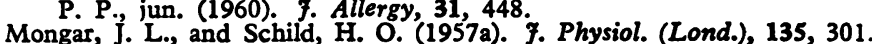

Mongar, J. L., and Schild, H. O. (1957a). F. Physiol. (Lond.), 135, 301

Mongar, J. L., and Schild, H. O. (1960). F. Physiol. (Lond.), 150, 546.

Noah, J. W., and Brand, A. (1955). F. Allergy, 26, 385.

Parish, W. E. (1967). Nature (Lond.), 215, 738.

Schild, H. O., Hawkins, D. F., Mongar, J. L., and Herxheimer, H. (1951). Lancet, $2,376$.

Sheard, P., Killingback, P. G., and Blair, A. M. J. N. (1967). Nature (Lond.), 216, 283.

VanArsdel, P. P., jun., Middleton, E., jun., Sherman: W. B., and Buchwald, H. (1958). F. Allergy, 29, 429. 